ACTA THERIOLOGICA

Vol. 28, 13: 209-224, 1983

\title{
Variability in Transferrins and Gamma-globulin Level of Blood Serum in the Common Vole ${ }^{1}$
}

\author{
Anna DOBROWOLSKA
}

\begin{abstract}
Dobrowolska A., 1973: Variability in transferrins and gamma-globulin level of blood serum in the common vole. Acta theriol., 28, 13: 209-224 [With 6 Tables \& 2 Figs.]

The level of gamma-globulins shows greater variability in young voles, Microtus arvalis (Pallas, 1779), as compared with middle-aged individuals. A particularly large variability of this index was observed in breeding voles captured in early summer. The correlation between the population density and variability in the level of gamma-globulins is significant for low-density populations (northern Poland), being positive for sexually nonactive voles, while negative for reproducing animals. The variability in transferrins was significantly correlated with population density for more abundant populations (southern Poland). The populations were characterized by a higher survival of heterozygotes in winter. It is concluded that water conditions of the habitat are responsible for these differences.

[Dept. Vertebr. Anim. Physiol., Warsaw Univ., Żwirki i Wigury 93, 02-089 Warszawa, Poland]
\end{abstract}

\section{INTRODUCTION}

Many authors (Anderson, 1970; Berry, 1970; Mather, 1970; Rasmussen, 1970) have emphasized that expanding populations are characterized by a broad spectrum of morphological, behavioural and genetic traits. This spectrum and its comparative analysis for geographically distant and ecologically different populations can provide a measure of adaptive and self-regulatory process, and also of the feedback: population differentiation - population density (Krebs, 1979).

Populations of the common vole Microtus arvalis (Pallas, 1779) inhabiting northern and southern parts of Poland (between which large differences in dynamics of numbers were found by Adamczewska-Andrzejewska, 1974) were interesting object of the study of genetic and physiological differentiation. Transferrin, a blood serum beta-globulin, was used as a marker of genetic variability (Dobrowolska, 1981), while differences in the level of blood serum gamma-globulins (immunoglobulins), which are proteins associated with immune processes, were used as an index of physiological differentiation in the population. In the

\footnotetext{
1 Badania były wykonane w ramach problemu węzłowego 09.1.7., koordynowanego przez Instytut Ekologii PAN.
} 
study, mostly the variability coefficient $(\mathrm{CV})$ was analysed to indicate the variability in the level of gamma-globulins.

As it has been expected that, according to Chitty's (1970) hypothesis, both these types of variability (genetic and physiological) can have some demographic consequences, these two indices of variability were compared with changes in population dynamics.

\section{MATERIAL AND METHODS}

Common voles were captured in 1973-1975, four times a year: in spring Sp (April), early summer - Se (June), late summer - Sl (August), and autumn $\mathrm{Au}$ (October), in northern (N) Poland (Mogilno and Bydgoszcz regions) and southern (S) Poland (Nysa and Brzeg regions). Northern populations were characterized by lower densities (a mean maximum of 237 voles/ha over the study period), as compared with southern populations (a mean maximum of 705 voles/ha, according to Adamczewska-Andrzejewska).

Voles were captured by flooding their burrows on 1-ha alfalfa fields. Samples of blood were taken under ether anaesthesia from the retro-orbital plexus, and then the animals were dissected to examine their breeding condition. They were aged using the eye-lens weight (Adamczewska-Andrzejewska, 1973), and classified into juvenile animals - juv. (no more than three months old), middle-aged animals - $\mathrm{ad}_{1}$ (from three to five months and older animals $-\mathrm{ad}_{2}$ (more than five months old). On the basis of the morphology of reproductive organs, the following classes of animals were distinguished: males sexually inactive (nA) and active (A), females that did not bear young at all (nA) and post partum females (pp), which were jointly considered as nonactive (nA), and the classes of pregnant ( $p$ ) and lactating (l) females, jointly considered as reproductively active (A).

Transferrins of blood serum were separated by the starch-gel electrophoresis technique under conditions described by Tomaszewska-Guszkiewicz et al. (1971), and identified by the Mueller et al. (1968) method. The pattern of the inheritance of transferrin allelomorphs has been presented by Dobrowolska (1981). It was assumed that they were an expression of two alleles: $T f^{F}$ (a common allele) and $T f^{E}$ (a rare allele) at an identical transferrin locus.

The level of gamma globulins was determined by paper electrophoresis under conditions described by Dżułyńska et al. (1969). The total protein content was determined by the Lowry method. Individual variability in the gamma-globulin level was tested by the variability coefficient (CV).

The chi-square test was used to analyse differences in the frequency of transferrin alleles. Correlation coefficients $(r)$ were calculated between the two types of variability and population density. The significance level of $p<0.05$ was used to find statistically significant $(S)$ differences and correlations. 


\section{RESULTS}

\subsection{Individual Variability in the Level of Gamma-globulins}

The variability coefficient was, on the average, higher for the group of juvenile voles $(\mathrm{N}, 17-51 \%, \mathrm{~S}, 16-63 \%)$ than for middle-aged voles ( N, $15-42 \%, \mathrm{~S}, 13-59 \%$ ), particularly in the class of reproducing individuals caught in early summer (Tables 1,2 ).

No significant differences were found in the differentiation of the gamma-globulin level with respect to sex, though in the group of

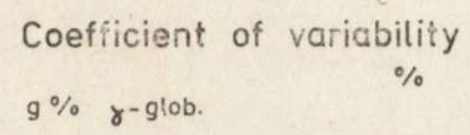

N
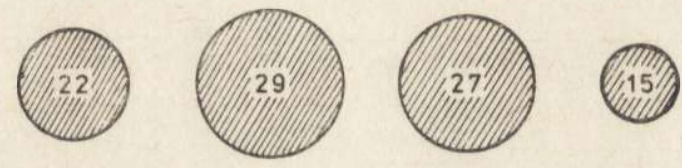

\&̊ A

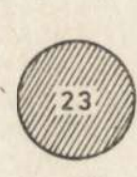

$\mathrm{Sp}$

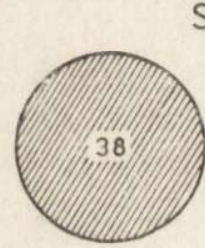

Se

S

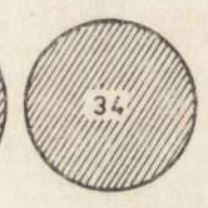

SI

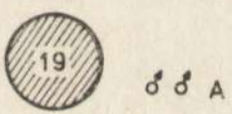

$\mathrm{Au}$

Fig. 1. Mean values of coefficient of variability $(\%)$ of serum gamma-globulin level in sexually active (A) vole males from northern (N) and southern (S) regions of Poland (S - spring, Se - early summer, S1 - late summer, A - autumn).

nonactive, middle-aged individuals $\left(\mathrm{ad}_{1}\right)$ caught in autumn in the southern region this differentiation was higher for females, while in the northern region for males (Tables 1,2 ). In most cases the variability of the gamma-globulin level was higher for reproductively nonactive than for active individuals in comparable age-classes. Higher values of the variability coefficient in the reproductively active voles mostly occurred in early summer (Se). There were differences in the individual variability of this parameters from season to season and from year to year. In northern populations it reached the highest values in early or late summer. In southern populations the maximum values were noted for males in summer, and for females either no seasonal differences were 
Table 1

Changes of serum gamma-globulin level and its coefficient of variability in voles Sample size-in

\begin{tabular}{|c|c|c|c|c|c|c|}
\hline \multirow{2}{*}{$\begin{array}{l}\text { Age } \\
\text { class }\end{array}$} & \multicolumn{4}{|c|}{1973} & \multicolumn{2}{|c|}{1974} \\
\hline & $\mathrm{Sp}$ & $\mathrm{Se}$ & $\mathrm{S} 1$ & $\mathrm{Au}$ & $\mathrm{Sp}$ & $\mathrm{Se}$ \\
\hline juv. & & $\begin{array}{l}0.61 \pm 0.06 \\
(9) \quad 31\end{array}$ & $\begin{array}{l}0.51 \pm 0.05 \\
(8) \quad 27\end{array}$ & $\begin{array}{l}0.83 \pm 0.14 \\
(9) \quad 48\end{array}$ & & $\begin{array}{l}\text { Nonactive } \\
0.52 \pm 0.05 \\
\text { (7) } \quad 26\end{array}$ \\
\hline $\mathrm{ad}_{1}$ & & & & $\begin{array}{r}1.23 \pm 0.09 \\
(14) \quad 30\end{array}$ & & \\
\hline $\mathrm{ad}_{1}$ & $\begin{array}{l}1.11 \pm 0.08 \\
(5) \quad 17\end{array}$ & $\begin{array}{l}0.72 \pm 0.12 \\
(5)\end{array}$ & $\begin{array}{lr}0.96 \pm 0.08 \\
(7) \quad 24\end{array}$ & $\begin{array}{l}0.87 \pm 0.11 \\
(3) \quad 22\end{array}$ & $\begin{array}{l}0.89 \pm 0.09 \\
(6) \quad 25\end{array}$ & $\begin{array}{l}\text { Active } \\
0.65 \pm 0.07 \\
\text { (5) } \quad 24\end{array}$ \\
\hline $\mathrm{ad}_{2}$ & $\begin{array}{l}1.20 \pm 0.07 \\
(7) \quad 19 \\
\end{array}$ & & & & $\begin{array}{l}0.97 \pm 0.07 \\
(14) \quad 28 \\
\end{array}$ & \\
\hline juv. & $\begin{array}{l}0.68 \pm 0.07 \\
(6) \quad 26\end{array}$ & $\begin{array}{lr}0.76 \pm 0.08 \\
(7) & 28\end{array}$ & $\begin{array}{l}0.70 \pm 0.10 \\
(4) \quad 28\end{array}$ & $\begin{array}{lr}0.91 \pm 0.08 \\
(3) & 29\end{array}$ & & $\begin{array}{l}\text { Nonactive } \\
0.52 \pm 0.04 \\
\text { (11) } 29\end{array}$ \\
\hline $\mathrm{ad}_{1}$ & & & $\begin{array}{l}1.70 \pm 0.22 \\
(4) \quad 23\end{array}$ & $\begin{array}{l}1.16 \pm 0.06 \\
(7) \quad 15\end{array}$ & $\begin{array}{l}1.08 \pm 0.07 \\
(4) \quad 13\end{array}$ & \\
\hline $\mathrm{ad}_{2}$ & & & & & $\begin{array}{l}0.90 \pm 0.07 \\
(15) \quad 35\end{array}$ & \\
\hline juv. & & $\begin{array}{l}0.98 \pm 0.13 \\
(4) \quad 26\end{array}$ & $\begin{array}{l}0.94 \pm 0.05 \\
(13) \quad 26\end{array}$ & & & $\begin{array}{l}\text { Pregnant } \\
0.78 \pm 0.14 \\
(8) \quad 50\end{array}$ \\
\hline $\mathrm{ad}_{1}$ & $\begin{array}{l}0.59 \pm 0.10 \\
(3) \quad 32\end{array}$ & $\begin{array}{l}0.83 \pm 0.06 \\
(4) \quad 15\end{array}$ & $\begin{array}{l}0.89 \pm 0.07 \\
(12) \quad 28\end{array}$ & $\begin{array}{l}0.83 \pm 0.12 \\
(3) \quad 25\end{array}$ & $\begin{array}{l}0.71 \pm 0.05 \\
(3) \quad 12\end{array}$ & $\begin{array}{l}0.60 \pm 0.09 \\
(3) \quad 28\end{array}$ \\
\hline $\mathrm{ad}_{2}$ & $\begin{array}{l}1.21 \pm 0.10 \\
(8) \quad 25\end{array}$ & & & & $\begin{array}{l}0.94 \pm 0.08 \\
(5) \quad 20\end{array}$ & \\
\hline juv. & & & $\begin{array}{l}0.66 \pm 0.02 \\
(5) \quad 23\end{array}$ & & & Lactating \\
\hline $\mathrm{ad}_{1}$ & $\begin{array}{l}1.07 \pm 0.11 \\
(9) \quad 35\end{array}$ & $\begin{array}{l}0.91 \pm 0.19 \\
(6) \quad 51\end{array}$ & $\begin{array}{l}1.06 \pm 0.18 \\
(6) \quad 41\end{array}$ & $\begin{array}{l}1.38 \pm 0.13 \\
(4) \quad 22\end{array}$ & & \\
\hline $\mathrm{ad}_{1}$ & & & $\begin{array}{l}0.66 \pm 0.12 \\
(3) \quad 33\end{array}$ & $\begin{array}{l}1.34 \pm 0.20 \\
(7) \quad 37\end{array}$ & & Post partum \\
\hline
\end{tabular}

Sp - spring, Se - early summer, Sl - late summer, Au - autumn; juv. -

recorded (1973, females $\mathrm{nA})$ or the highest values of the variability coefficients were noted in early summer (1974) and autumn (1975) (Table 3). Most regular seasonal differences in variability coefficient for northern and southern voles populations occurred in the sexually active, reproducing males (Fig. 1).

Comparing the results obtained for successive years, it was noted that seasonal changes in the variability coefficient of northern voles were similar in particular years, while for southern voles the year of increased numbers (1974) showed a marked difference as compared with all the other years. In the early summer of this year, the variability coefficient for both active and nonactive individuals of both sexes 
from northern populations (mean $\pm \mathrm{SE} ; \mathrm{CV}, \%$ - in lower position), parentheses.

\begin{tabular}{|c|c|c|c|c|c|}
\hline \multicolumn{2}{|l|}{1974} & \multicolumn{4}{|c|}{1975} \\
\hline Sl & $\mathrm{Au}$ & $\mathrm{Sp}$ & $\mathrm{Se}$ & Sl & $\mathrm{Au}$ \\
\hline $\begin{array}{c}\text { Males } \\
0.75 \pm 0.06 \\
(16) \quad 36\end{array}$ & $\begin{array}{l}1.25 \pm 0.08 \\
(10) \quad 18\end{array}$ & & $\begin{array}{l}0.80 \pm 0.12 \\
(4) \quad 30\end{array}$ & $\begin{array}{l}0.93 \pm 0.08 \\
(8) \quad 26\end{array}$ & $\begin{array}{l}1.11 \pm 0.16 \\
(7) \quad 38\end{array}$ \\
\hline & $\begin{array}{l}1.42 \pm 0.08 \\
(19) \quad 26\end{array}$ & & & & $\begin{array}{l}1.03 \pm 0.10 \\
(16) \quad 40\end{array}$ \\
\hline $\begin{array}{l}\text { Males } \\
1.19 \pm 0.16\end{array}$ & $1.48 \pm 0.09$ & $1.22 \pm 0.11$ & $0.94 \pm 0.10$ & $1.31 \pm 0.12$ & \\
\hline (6) 34 & (3) $\quad 11$ & (3) 16 & (4) 30 & (7) $\quad 25$ & (4) 14 \\
\hline & & $\begin{array}{l}1.27 \pm 0.14 \\
\text { (11) } 32 \\
\end{array}$ & & & \\
\hline $\begin{array}{l}\text { Females } \\
1.04 \pm 0.26 \\
\text { (4) } 44\end{array}$ & $\begin{array}{l}1.01 \pm 0.08 \\
(7) \quad 23\end{array}$ & & $\begin{array}{l}0.52 \pm 0.09 \\
(5) \quad 41\end{array}$ & $\begin{array}{l}0.93 \pm 0.04 \\
(4) \quad 10\end{array}$ & $\begin{array}{l}0.95 \pm 0.05 \\
(11) \quad 17\end{array}$ \\
\hline $1.70 \pm 0.23$ & $1.41 \pm 0.05$ & & & $1.36 \pm 0.17$ & $1.35 \pm 0.14$ \\
\hline (7) $\quad 23$ & (15) 15 & & & (3) 22 & (8) 30 \\
\hline & & $\begin{array}{l}1.21 \pm 0.05 \\
(3) \quad 9\end{array}$ & & & \\
\hline $\begin{array}{l}\text { Females } \\
082 \pm 0.07\end{array}$ & & & $0.75 \pm 0.14$ & $0.81 \pm 0.09$ & \\
\hline (4) 19 & & & (6) 46 & (7) 31 & \\
\hline $1.08 \pm 0.11$ & $1.69 \pm 0.25$ & $1.10 \pm 0.25$ & $0.87 \pm 0.07$ & $1.16 \pm 0.07$ & \\
\hline (8) 32 & (7) $\quad 39$ & (3) 32 & (4) 31 & (7) 22 & \\
\hline & & $\begin{array}{l}1.23 \pm 0.12 \\
(10) \quad 32\end{array}$ & & & \\
\hline $\begin{array}{l}\text { Females } \\
1.14 \pm 0.13 \\
(7) \quad 32\end{array}$ & & & & $\begin{array}{l}1.35 \pm 0.16 \\
(4) \quad 25\end{array}$ & \\
\hline $1.05 \pm 0.10$ & $1.90 \pm 0.23$ & & $0.65 \pm 0.10$ & $1.06 \pm 0.16$ & \\
\hline $\begin{array}{l}\text { (6) } \\
\text { Females }\end{array}$ & (4) $\quad 29$ & & (4) 38 & (7) $\quad 39$ & \\
\hline $1.44 \pm 0.23$ & $1.76 \pm 0.17$ & & $1.09 \pm 0.10$ & $1.70 \pm 0.18$ & \\
\hline (6) $\quad 39$ & (7) 26 & & (15) 36 & (5) & \\
\hline
\end{tabular}

juvenile, $\mathrm{ad}_{1}$ - adults, $\mathrm{ad}_{2}$ - older adults

reached much higher values $(55-63 \%$ for males and $13-59 \%$ for females, Table 2) than in the same season of the other years (13-44\% in general, Table 2). This high variability in the level of gamma-globulins observed in early summer was followed by a high value of gammaglobulins in the late period (late summer - Sl, Fig. 2).

The variability coefficient of the gamma-globulin level was higher for animals from dense southern populations $(12-59 \%)$, as compared with less dense northern populations $(11-42 \%)$ (Table 3$)$. A higher variability of the gamma-globulin level was coupled with higher mean values of the protein fraction (Table 1 and 2, Fig. 2).

The correlation between the mean variability coefficients of gamma- 
Table 2

Changes of serum gamma-globulin level and its coefficient of variability in voles

\begin{tabular}{|c|c|c|c|c|c|c|}
\hline \multirow{2}{*}{$\begin{array}{l}\text { Age } \\
\text { class }\end{array}$} & \multicolumn{4}{|c|}{1973} & \multicolumn{2}{|r|}{1974} \\
\hline & $\mathrm{Sp}$ & $\mathrm{Se}$ & $\mathrm{S} 1$ & $\mathrm{Au}$ & $\mathrm{Sp}$ & $\mathrm{Se}$ \\
\hline juv. & $\begin{array}{l}0.81 \pm 0.07 \\
(9) \quad 28\end{array}$ & $\begin{array}{l}0.85 \pm 0.09 \\
(7) \quad 27\end{array}$ & $\begin{array}{l}0.67 \pm 0.07 \\
(16) \quad 46\end{array}$ & $\begin{array}{l}0.70 \pm 0.09 \\
(9) \quad 39\end{array}$ & & $\begin{array}{l}\text { Nonactive } \\
0.51 \pm 0.06 \\
\text { (18) } 55\end{array}$ \\
\hline $\mathrm{ad}_{1}$ & & & Active & $\begin{array}{l}1.03 \pm 0.11 \\
(9) \\
\text { les }\end{array}$ & & \\
\hline juv. & & $\begin{array}{l}0.78 \pm 0.04 \\
(16) \quad 18\end{array}$ & Receve gore & & & $\begin{array}{l}0.54 \pm 0.15 \\
(3) \quad 63\end{array}$ \\
\hline $\mathrm{ad}_{1}$ & $\begin{array}{l}0.77 \pm 0.15 \\
(5) \quad 34\end{array}$ & $\begin{array}{l}0.86 \pm 0.06 \\
(3) \quad 13\end{array}$ & $\begin{array}{l}0.93 \pm 0.10 \\
(12) \quad 39\end{array}$ & $\begin{array}{l}1.51 \pm 0.22 \\
(3) \quad 25\end{array}$ & $\begin{array}{l}0.88 \pm 0.05 \\
(10) \quad 20\end{array}$ & $\begin{array}{l}(3) \\
0.80 \pm 0.14 \\
(10) \quad 59\end{array}$ \\
\hline $\mathrm{ad}_{2}$ & $\begin{array}{l}1.29 \pm 0.10 \\
(12) \quad 17\end{array}$ & 年 & & & $\begin{array}{l}1.07 \pm 0.06 \\
(18) \quad 26\end{array}$ & \\
\hline juv. & $0.64 \pm 0.06$ & $0.76 \pm 0.07$ & $0.75 \pm 0.07$ & $0.78 \pm 0.13$ & & $\begin{array}{l}\text { Nonactive } \\
0.50 \pm 0.05\end{array}$ \\
\hline $\mathrm{ad}_{1}$ & (11) 34 & (16) 34 & $\begin{array}{l}(16) \quad 37 \\
0.72 \pm 0.09 \\
(5) \quad 29\end{array}$ & $\begin{array}{lr}(6) & 38 \\
1.02 \pm 0.12 \\
(14) \quad 47\end{array}$ & & $\begin{array}{l}\text { (17) } 45 \\
\text { Pregnant }\end{array}$ \\
\hline juv. & & $\begin{array}{l}0.92 \pm 0.07 \\
(6) \quad 18\end{array}$ & $\begin{array}{l}0.82 \pm 0.09 \\
(9) \quad 35\end{array}$ & & & $\begin{array}{l}0.41 \pm 0.08 \\
(4) \quad 40\end{array}$ \\
\hline $\begin{array}{l}\mathrm{ad}_{1} \\
\mathrm{ad}_{2}\end{array}$ & $\begin{array}{l}0.76 \pm 0.13 \\
(7) \quad 45 \\
1.02 \pm 0.09\end{array}$ & $\begin{array}{l}1.02 \pm 0.04 \\
(9) \quad 13\end{array}$ & $\begin{array}{l}0.94 \pm 0.10 \\
(12) \quad 40\end{array}$ & & $\begin{array}{l}0.83 \pm 0.10 \\
(12) \quad 43 \\
0.96 \pm 0.04\end{array}$ & $\begin{array}{l}0.65 \pm 0.10 \\
(14) \quad 57\end{array}$ \\
\hline & (17) 35 & & & & (31) 26 & \\
\hline $\mathrm{ad}_{1}$ & & $\begin{array}{l}0.79 \pm 0.11 \\
(4) \quad 22\end{array}$ & $\begin{array}{l}0.91 \pm 0.08 \\
(5) \quad 20\end{array}$ & , & & $\begin{array}{l}\text { Lactating } \\
0.74 \pm 0.13 \\
(10) \quad 59\end{array}$ \\
\hline $\mathrm{ad}_{2}$ & & $\begin{array}{l}1.32 \pm 0.05 \\
(3) \quad 17\end{array}$ & & & & $\begin{array}{l}0.85 \pm 0.05 \\
(5) \quad 13 \\
\text { Post partum }\end{array}$ \\
\hline $\mathrm{ad}_{1}$ & & $\begin{array}{l}0.85 \pm 0.11 \\
(4) \quad 33\end{array}$ & $\begin{array}{l}0.86 \pm 0.13 \\
(5) \quad 35\end{array}$ & $\begin{array}{l}0.64 \pm 0.15 \\
(4) \quad 49\end{array}$ & & \\
\hline $\mathrm{ad}_{2}$ & 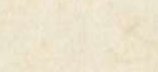 & & & $\begin{array}{l}0.68 \pm 0.11 \\
(3) \quad 24\end{array}$ & $\begin{array}{l}1.04 \pm 0.12 \\
(7) \quad 35\end{array}$ & \\
\hline
\end{tabular}

Sp - spring, Se - early summer, Sl - late summer, Au - autumn; juv. -

globulin level and the density of the populations both southern and northern was positive for sexually nonactive individuals and negative for reproducing voles (regression coefficient $-\mathrm{S}$ for males and females jointly from the northern populations, Tables 3 and 6$)$.

\subsection{Variability in Transferrins}

Changes in the frequency of $T f^{F}$ allele were parallel in northern and southern populations. A decrease in the frequency of this allele was observed in the late summer of 1974 and already at the beginning of 
from southern populations (mean $\pm \mathrm{SE} ; \mathrm{CV}, \%$ - in lower position). in parentheses.

\begin{tabular}{|c|c|c|c|c|c|}
\hline \multicolumn{2}{|l|}{1974} & \multicolumn{4}{|c|}{1975} \\
\hline S1 & $\mathrm{Au}$ & $\mathrm{Sp}$ & Se & S1 & $\mathrm{Au}$ \\
\hline \multicolumn{6}{|l|}{ Males } \\
\hline $1.07 \pm 0.12$ & $1.06 \pm 0.11$ & & $0.56 \pm 0.03$ & $0.84 \pm 0.10$ & $0.86 \pm 0.07$ \\
\hline \multirow{3}{*}{ (6) 45} & & & & & \\
\hline & $\begin{array}{l}1.33 \pm 0.09 \\
(15) \quad 28\end{array}$ & & & & $\begin{array}{l}1.12 \pm 0.12 \\
(31) \quad 36\end{array}$ \\
\hline & & & $\begin{array}{l}0.84 \pm 0.15 \\
(4) \quad 40\end{array}$ & & \\
\hline \multirow{3}{*}{ (12) 33} & $1.60 \pm 0.11$ & $1.27 \pm 0.09$ & $0.64 \pm 0.10$ & $1.08 \pm 0.09$ & $1.75 \pm 0.22$ \\
\hline & (4) 12 & & (13) 44 & (14) 32 & (3) 22 \\
\hline & & $\begin{array}{l}1.31 \pm 0.10 \\
(9) \quad 23\end{array}$ & & & \\
\hline $\begin{array}{c}\text { Females } \\
2.02 \pm 0.16\end{array}$ & $1.12 \pm 0.13$ & & $0.70 \pm 0.04$ & $0.86 \pm 0.07$ & $0.75 \pm 0.10$ \\
\hline $\begin{array}{lr}(4) & 16 \\
1.56 \pm 0.11 \\
(4) & 17\end{array}$ & $\begin{array}{lc}(10) & 36 \\
1.2 \pm 0.14 \\
(13) & 43\end{array}$ & & (21) 27 & $\begin{array}{lr}(8) & 33 \\
1.34 \pm 0.16 \\
(6) & 29\end{array}$ & $\begin{array}{lr}(10) & 43 \\
1.34 \pm 0.25 \\
(6)\end{array}$ \\
\hline \multirow[t]{2}{*}{ Females } & & & & & \\
\hline & & & $\begin{array}{l}0.58 \pm 0.11 \\
(4) \quad 40\end{array}$ & $\begin{array}{l}0.81 \pm 0.09 \\
(7) \quad 31\end{array}$ & \\
\hline \multirow{3}{*}{ (12) 40} & & $1.40 \pm 0.12$ & $0.64 \pm 0.22$ & $1.34 \pm 0.14$ & $1.15 \pm 0.15$ \\
\hline & & (7) 23 & (4) 23 & (8) $\quad 29$ & (12) 39 \\
\hline & & $\begin{array}{l}1.48 \pm 0.13 \\
(11) \quad 27\end{array}$ & & & \\
\hline \multirow{2}{*}{$\begin{array}{r}\text { Females } \\
1.29 \pm 0.08\end{array}$} & & & & & \\
\hline & & & $0.85 \pm 0.12$ & & $1.14 \pm 0.08$ \\
\hline \multirow[t]{2}{*}{ (4) 13} & & 1 & (4) 28 & & (11) 24 \\
\hline & & & $\begin{array}{l}1.24 \pm 0.25 \\
(4) \quad 26\end{array}$ & & \\
\hline $\begin{array}{l}\text { Females } \\
1.22 \pm 0.15\end{array}$ & $1.75 \pm 0.17$ & & & $1.07 \pm 0.17$ & $1.26 \pm 0.15$ \\
\hline \multirow[t]{2}{*}{ (10) 39} & (7) $\quad 26$ & & & (11) 54 & (5) 34 \\
\hline & & & & & $\begin{array}{l}2.21 \pm 0.46 \\
(4) \quad 42\end{array}$ \\
\hline
\end{tabular}

juveniles, $\mathrm{ad}_{1}-$ adults, $\mathrm{ad}_{2}-$ older adults.

the breeding season in the spring of 1975 (Table 4). In 1975, the frequency of alleles in the whole population was affected by the frequencies in the group of females. In both populations the cohort of overwintered females as well as the early summer cohort of females were both characterized by a large number of heterozygotes and, consequently, the frequency of the common $T f^{F}$ allele was lower (Table 5). The lowest frequencies of this allele occurred in males in early summer. Seasonal changes in the frequency of alleles both in the northern (1974) and southern $(1974,1975)$ populations were statistically significant when 


\section{Table 3}

Coefficient of variability $(\%)$ in gamma-globulin level in sexual active and inactive males and females of voles from northern and southern populations.

\begin{tabular}{|c|c|c|c|c|c|c|c|c|c|c|c|c|}
\hline \multirow{2}{*}{$\begin{array}{l}\text { Sex and } \\
\text { class }\end{array}$} & \multicolumn{4}{|c|}{1973} & \multicolumn{4}{|c|}{1974} & \multicolumn{4}{|c|}{1975} \\
\hline & Sp & $\mathrm{Se}$ & S1 & $\mathrm{Au}$ & $\mathrm{Sp}$ & $\mathrm{Se}$ & S1 & $\mathrm{Au}$ & Sp & $\mathrm{Se}$ & $\mathrm{Sl}$ & $\mathrm{Au}$ \\
\hline \multicolumn{13}{|c|}{ Northern population } \\
\hline $\mathrm{nA}$ & - & 31 & 27 & 39 & - & 26 & 36 & 22 & - & 30 & 26 & 39 \\
\hline A & 18 & 35 & 24 & 22 & 26 & 24 & 34 & 11 & 24 & - & 25 & 14 \\
\hline $\mathrm{nA}$ & 26 & 28 & 34 & 26 & 23 & 29 & 35 & 28 & - & 42 & 26 & 23 \\
\hline \multirow{2}{*}{$\mathrm{N}^{\mathrm{A}}$} & 30 & 30 & 32 & 23 & 16 & 39 & 27 & 34 & 32 & 26 & 29 & 23 \\
\hline & 5 & 4 & 21 & 148 & 12 & 9 & 52 & 121 & 19 & 25 & 140 & 237 \\
\hline
\end{tabular}

Southern population

\begin{tabular}{rrrrrrrrrrrrrr} 
M & nA & 28 & 27 & 46 & 35 & - & 55 & 45 & 27 & - & 27 & 33 & 32 \\
& $\mathrm{~A}$ & 25 & 15 & 39 & 25 & 23 & 59 & 33 & 12 & 22 & 44 & 32 & 22 \\
$\mathrm{~F}$ & $\mathrm{nA}$ & 34 & 34 & 34 & 38 & - & 45 & 24 & 35 & - & 27 & 41 & 42 \\
& $\mathrm{~A}$ & 40 & 19 & 31 & - & 34 & 42 & 26 & - & 25 & 30 & 30 & 31 \\
& $\mathrm{~N}$ & 15 & 29 & 313 & 449 & 96 & 122 & 534 & 705 & 25 & 61 & 90 & 149 \\
\hline
\end{tabular}

Sp - spring, Se - early summer, S1 - late summer, Au - autumn, nA -
sexually inactive $\mathrm{A}$ - sexually active, $\mathrm{N}$ - number/ha, after Adamczewska-Andrzejewska, unpubl. data.

they were tested with chi-square test. The elimination rate of $T f^{F}$ allele in the winter of $1974 / 1975$, mostly due to the elimination of heterozygotes, was the same for both northern and southern populations (North p-Sp, 1975/p-Au, 1974=1.01, South p-Sp, 1975/p-Au, 1974=1.01)

Time-related changes in the allele frequency at the transferrin locus

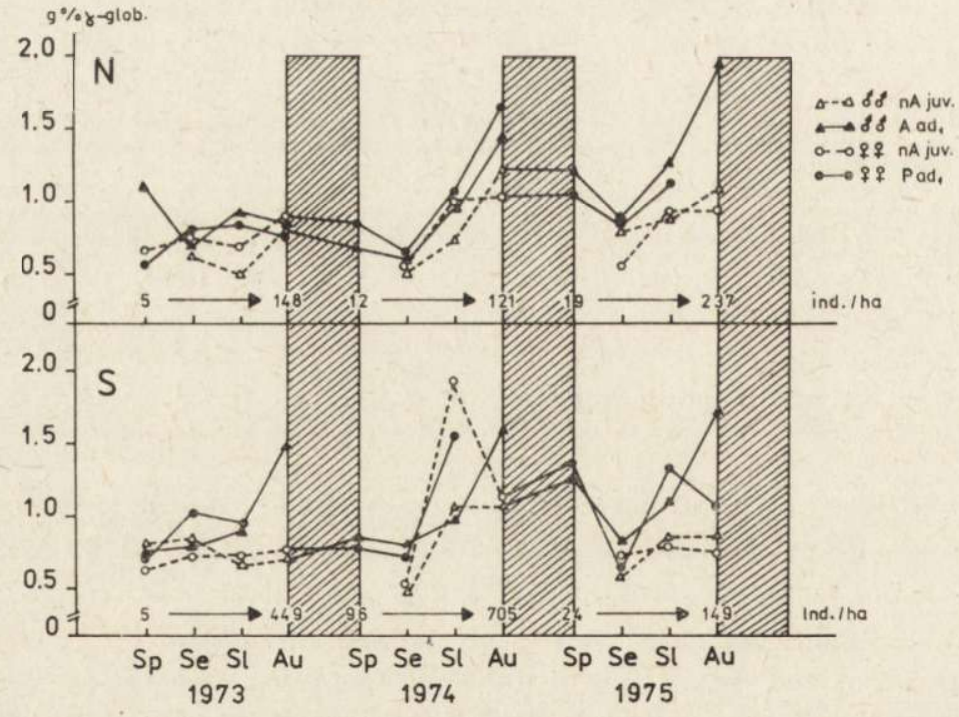

Fig. 2. Seasonal changes in blood serum gamma-globulin level in common voles from northern $(\mathrm{N})$ and southern $(\mathrm{S})$ populations and annual increases of the population densities (ind./ha) ( $\mathrm{nA}$ juv. - sexually nonactive, juvenile; $\mathrm{A} \mathrm{ad}_{1}$ sexually active, adults; $\mathrm{p} \mathrm{ad}_{1}$ - pregnant, adults). 
Table 4

Frequencies of $T f^{F}$ allele (p) in Microtus arvalis population from northern and southern Poland.

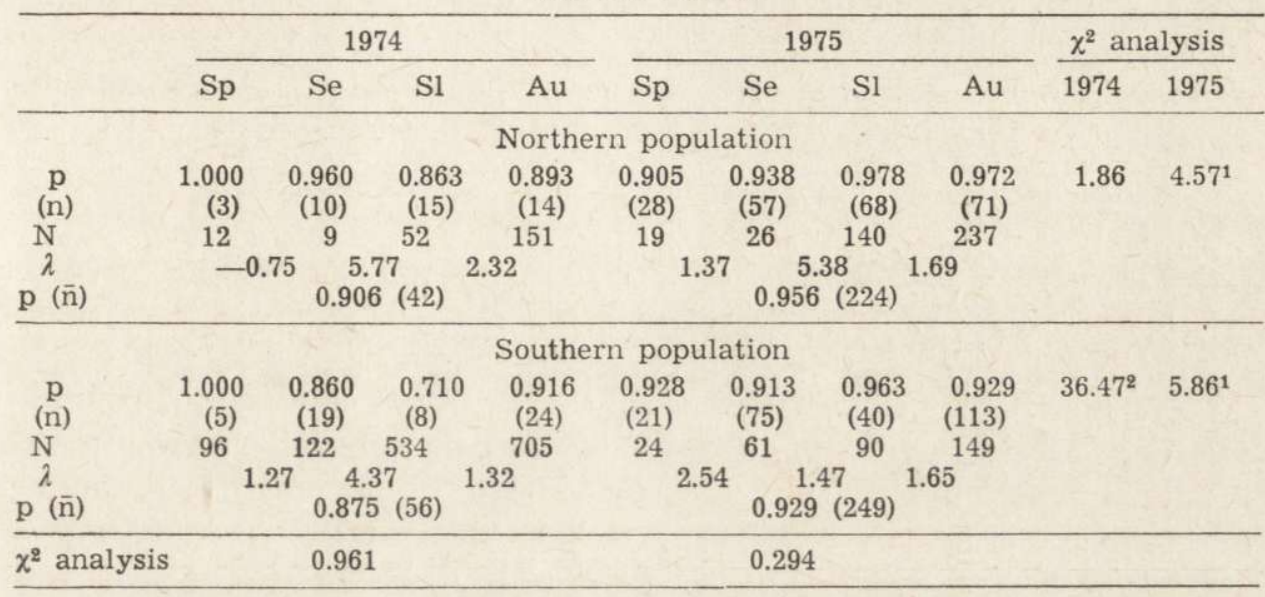

(n) - sample size, N - number of individuals/ha, after Adamczewska-Andrzejewska unpubl. data, Sp - spring, Se - early summer, Sl - late summer, $\mathrm{Au}$ - autumn

${ }^{1} p<0.05,{ }^{2} p<0.01 \quad i=\frac{\mathrm{N}_{\mathrm{t}+1}}{\mathrm{~N}_{\mathrm{t}}} \quad p=\sum \frac{\mathrm{n}_{\mathrm{i}}}{\mathrm{n}} p_{i}$

Weight mean frequency for 1975 and 1976 in northern population is $0.948(n=266)$, in southern population is $0.919(n=3053)$. (difference $S, \chi^{2}=12.18$ ).

were similar at different number dynamics for the two populations in successive years. Correlation between the frequency of alleles and density of northern vole populations were not statistically significant $(p<0.05)$. In southern populations of common $T f^{F}$ allele was significantly eliminated with increase of density (Table 6).

In the northern region, where smaller fluctuations in number were observed (Adamczewska-Andrzejewska, 1974), the differentiation of

Table 5

Frequencies of transferrin allele $T f^{F}$ in males and females from northern and southern populations in 1975 (sample size - in parentheses).

\begin{tabular}{llllll}
\hline \multirow{2}{*}{ Sex } & \multicolumn{9}{c}{1975} & \multirow{2}{*}{$\chi^{2}$ analysis } \\
\cline { 2 - 5 } & Sp & Se & S1 & Au & \\
Males & $1.000(3)$ & $0.923(21)$ & $0.928(14)$ & $0.974(39)$ & $4.47^{1}$ \\
Females & $0.833(12)$ & $0.954(33)$ & $0.990(54)$ & $0.969(33)$ & $10.75^{1}$ \\
\hline \multicolumn{7}{c}{ Northern population } \\
Males & $1.000(15)$ & $0.919(37)$ & $0.950(20)$ & $0.955(56)$ & 3.44 \\
Females & $0.846(13)$ & $0.910(39)$ & $0.980(25)$ & $0.903(57)$ & $7.06^{1}$ \\
\hline
\end{tabular}

$\mathrm{Sp}$ - spring, Se - early summer, Sl - late summer, Au - autumn; $1 p<0.05$ 
voles, measured with frequencies of the common $T f^{F}$ allele, was lower (greater frequencies 0.948 on the average) than in the southern region (lower mean frequencies 0.919 ) and the differences were statistically significant (Table 4).

No differences were recorded in the frequency of $T f$ alleles between groups of animals differed in age and reproductive activity.

\section{DISCUSSION}

\subsection{Variability in the Level of Gamma-globulins}

It has been assumed that individual variability in the level of gammaglobulins reflects the effects of the internal environment (hormonal regulation) and the external environment (potential antigens occurring

\section{Table 6}

Correlation between coefficient of variability $(\mathrm{C} / \mathrm{V})$ in gamma-globulin level and number of animals $(\mathrm{N})$ and between frequencies of $T f^{F}$ allele (p) and number parameters $(\mathrm{N}, \lambda)$.

\begin{tabular}{|c|c|c|c|c|c|}
\hline \multirow{2}{*}{\multicolumn{2}{|c|}{ Correlation }} & \multicolumn{2}{|c|}{ Northern } & \multicolumn{2}{|c|}{ Southern } \\
\hline & & $\mathrm{n}$ & $r$ & $\mathrm{n}$ & $r$ \\
\hline \multicolumn{6}{|l|}{$\mathrm{CV} \times \mathrm{N}$} \\
\hline Males & $\mathrm{nA}$ & $\begin{array}{r}9 \\
11\end{array}$ & $\begin{array}{r}0.41 \\
-0.531\end{array}$ & $\begin{array}{l}10 \\
12\end{array}$ & 0.13 \\
\hline \multirow[t]{2}{*}{ Females } & $\mathrm{nA}$ & 11 & $\begin{array}{l}-0.53^{1} \\
0.40\end{array}$ & $\begin{array}{l}12 \\
10\end{array}$ & $\begin{array}{r}-0.18 \\
0.18\end{array}$ \\
\hline & A & 12 & -0.27 & 10 & -0.26 \\
\hline$(\mathrm{M}+\mathrm{F})$ & A & 12 & $-0.56^{1}$ & 12 & -0.25 \\
\hline $\begin{array}{l}p \times N \\
p \times \lambda\end{array}$ & & $\begin{array}{l}7 \\
6\end{array}$ & $\begin{array}{r}0.23 \\
-0.30\end{array}$ & $\begin{array}{l}8 \\
6\end{array}$ & $\begin{array}{l}-0.50 \\
-0.84^{1}\end{array}$ \\
\hline
\end{tabular}

$\mathrm{N}$ - number of individuals/ha, after Adamczewska-Andrzejewska, unpubl. data; $\mathrm{M}$ - males, $\mathrm{F}$ - females, $\mathrm{nA}$ - inactive, $\mathrm{A}$ - sexually active.

$\lambda=\frac{\mathrm{N} t+1}{\mathrm{Nt}_{\mathrm{t}}}, p<0.05$

in an environment) on the organism, and that the differentiation of individual immune responses is a measure of adaptation of the population with respect to this character studied. A large range of the variability coefficient (from 11 to $63 \%$ ) and its high mean value (about $30 \%$ ) would indicate that the variability in the level of gamma-globulins in the blood serum of common voles is of a great functional and adaptative importance. It is interesting that mean values of the variability coefficient of the level of gamma-globulins was similar to that observed in other small mammals for morpho-physiological indices such as the weight of spleen and adrenal glands (Schwarz et al., 1964; Pucek, 1965). In view of this fact it can be suggested that the degrees of 
functional adaptation of the weight of spleen, adrenal glands, and of the level of gamma-globulins are similar. This would be an argument supporting their co-action in resistance processes at the individual level.

A greater individual variability in the level of gamma-globulins recorded for young and sexually nonactive animals as compared with older and active ones is consistent with many observations concerning morpho-physiological variability (Schwarz et al., 1964; Pucek 1965, and others) and physiological variability (Kostelecka-Myrcha \& Myrcha, 1967) for small mammals. A large differentiation observed in the youngest males already sexually active could result from their differentiated response to increasing effects of hormones during the process of sexual maturation of still young organisms. A high individual variability in the levels of androgens and gamma-globulins ( $\mathrm{ca} 35 \%$ ) was observed in young common voles raised in the laboratory (Dobrowolska \& Gromadzka-Ostrowska, 1982). Similarly, hormonal conditioning could account for a great variability in the level of gamma-globulins, as well as for lack of a recurrent seasonal pattern from year to year, in the group of sexually active females. For female voles, the greatest variability in the level of gamma-globulin was observed in oestrus the period of hormonal excitement, as compared with other phases of the oestrus cycle (Dobrowolska, 1982b).

In early summer the level of gamma-globulins were small, which could result from a deficiency of these proteins at that time (Dobrowolska, 1980). A high individual variability in the level of gammaglobulins observed at that time could be explained by an immunosuppressive action of hormones in the breeding period. This high variability occurring in summer could also be an effect of a populational and physiological hierarchy of individuals born in spring with respect to their position of dominance in the population, since from the physiological point of view the fact of the mating of dominant males with dominant females, or subordinate individuals, could be important. The offspring of the latter, which are subject to social stress, could be immunologically inferior. They would suffer a deficiency of antibodies caused by underdevelopment of the lymphoid tissue of the etmbryo as the result of a depressive action of increased amounts of adrenal steroids in utero.

Intriguing is a high variability observed in early summer of the year of increased vole population density in the southern region (1974). It is difficult to tell what the cause was, but the occurrence of high values of the variability coefficient in all physiological- and age-classes of animals would suggest that environmental effects were of major importance at that time. It is possible that the earlier appearance of 
the peak in the action of environmental antigens differentiated the population in such a way that as a result of the selection occurring in summer, only the individuals with higher levels of immunoglobulins remained, characterized by a higher survival rate and together with newborn voles they formed a more dense autumn population.

It seems that the high variability in the level of gamma-globulins of blood serum in late summer could reflect both the diversified response of voles to increasing amounts of antigens in their environment and endocrinal influencies. Instead, the high level of variability in this protein fraction in the blood serum of nonactive males and females in autumn would give them greater adaptive possibilities in contrast to the selected and at that time not abundant groups of sexually active males.

\subsection{Variability in Transferrins}

Differences in the pattern of changes in $T f$ allele frequency between females and males support the earlier views on differncees in the course of selection for both sexes of voles (Dobrowolska, 1981a). This observation obtained form $M$. arvalis is consisted with earlier observations for other voles species (Tamarin \& Krebs, 1969, Gaines \& Krebs, 1971).

In earlier studies on the variability of transferrins in $M$. arvalis, an increase in the number of heterozygotes during the breeding season (especially in late summer) was observed for two successive years with not high density of vole population. In the year with higher vole density, however, the great number of heterozygous males was already observed in spring and early summer (in the group of animals that survived winter and in these from the spring cohort, Dobrowolska, 1982a). Also in this study an increase in the number of heterozygotes (as expressed by a decrease in the frequency of the common $T f^{F}$ allele) in one year (1974) occurred in the period of population growth (late summer), while in the following year (1975) the number of heterozygotes was the highest in spring and early summer. These two observations imply that in some years the genetic changes correlate with increasing population number while in other it is not. It was stated for the southern populations studied earlier (Dobrowolska, 1981, 1982a) as well as for the southern populations analysed here, that the increase in numbers in a given year is preseded by an increased survival rate of heterozygous males (Dobrowolska, 1981) or females (present results) in winter and spring. The significance of differences in the genetic composition of the population in different phases of its growth is supported by Fedyk \& Gębczyński (1980), who have found that the genetic distance 
between generations is higher than within each of these generations.

The parallelism of changes in the frequency of alleles for geographically distant populations (South and North of Poland) seems to be interesting, providing evidence for a similar selection with time. This fact could indicate that the same superior factor of selection act in various geographical areas. Gaines et al. (1978) have found a similar relationship for Microtus ochrogaster (Baird, 1858), for which changes in the frequency of the $T f$ gene with population numbers were not recurrent in time (from year to year) but were similar in space.

In $M$. arvalis more heterozygotes were noted at higher densities, as was the case in Microtus agrestis (Linnaeus, 1761) from northern and southern Sweden, or in Microtus ochrogaster from different areas of Kansas, USA (Gaines et al., 1978). As it has been found, heterozygotes can be more active and aggressive (Garten, 1977), thus it may be expected that they have more interactions with other individuals, and this, in turn, can have some demographic consequences.

\subsection{General Remarks}

Comparing the genetic and physiological variability, it can be stated that they both reflected different selection pressures in particular seasons and years. The variability in the physiological parameter under study seems to be more sensitive and more closely correlated with population density than the genetic variability. This is likely to be an effect of a direct relation between the physiological character as the immunoglobulin level (humoral resistance) and potential possibilities of individuals to survive in the population. The character of relationship between physiological variability and population density was similar for the two populations studied. Generally, an increased density was coupled with a greater variability in gamma-globulin level for sexually inactive animals, and with its lower variability in the parameter for the active animals, probably subjected to a greater selection pressure.

Differences between geographically distant populations seem to be important. In the southern populations, characterized by higher densities as compared with northern populations, both the number of heterozygotes and the variability in the physiological parameter were greater. This can provide an indication that the southern populations have greater adaptability, according to the Schwarz principle $(1975$, quoted by Petrusewicz, 1978). In the populations there was genetic variability which was significantly related to population numbers. In the northern populations, characterized by lower densities and less variable with 
respect to the genetic marker and the physiological trait under study, the variability in this physiological parameters was significantly correlated with density.

These differences in variability and their relation to numbers can result from differences in selection between the two study regions. Differences in selection based on the survival of various genotypes of Microtus arvalis from geographically distant populations were explained by differences in air temperature (Ranshendakin \& Burmakin, 1979). It seems that in the case of the populations studied in Poland, humidity and soil moisture (higher in the southern region) may be of greater importance than temperature (similar in the both regions) with respect to differences in selection and variability. The density of the populations studied here was not univocally correlated with temperature: a temperature close to the average of a year represented an optimum for population growth (Adamczewska-Andrzejewska, 1980). Although precipitation alone had no effect on population growth (AdamczewskaAndrzejewska, 1980), humidity as measured by the amount of dew (two times greater in southern than in northern region) seems to have an effect on the amount of water in food and in vole tissues (blood), and differences in selection by physiological processes.

Acknowledgements: I wish to thank Professor J. Gill and Professor R. Andrzejewski for their care and discussion in the course of this study. Grateful acknowledgement is extended to Dr. K. Adamczewska-Andrzejewska for her help, assistance and information on population densities in the study area, and to Professor Z. Pucek and Dr. M. Gębczyński for valuable comments on the manuscript.

\section{REFERENCES}

1. Adamczewska-Andrzejewska K., 1973: The lens weight as indicator of age in the wild Microtus arvalis population. Bull. Acad. Pol. Sci., Ser. Sci. biol., 21: $331-335$.

2. Adamczewska-Andrzejewska K., 1974: Prognozowanie zmian zagęszczenia nornika polnego (Microtus arvalis, Pall.) w oparciu o pogłębioną analizę populacji. Biul. IOR, 57: 393-400.

3. Adamczewska-Andrzejewska K., 1979: The dependence of the population parameters of Microtus arvalis (Pallas, 1779) on air temperature and precipitation. Bull. Acad. Pol. Sci., Ser. Sci. biol., 27: 353-358.

4. Anderson P. K., 1970: Ecological structure and gene flow in small mammals. Symp. zool. Soc. Lond., 26: 299-325.

5. Berry R. J., 1970: Covert and overt variation as exemplified by British mouse populations. Symp. zool. Soc. Lond., 26: 3-26.

6. Chitty D., 1970: Variation and population density. Symp. zool. Soc. Lond., 26: $327-333$.

7. Dobrowolska A., 1980: [Seasonal changes of gamma-globulin level in blood 
serum of voles (Microtus arvalis, Pallas, 1779) from free living populations]. $\mathrm{Ph}$. D. Thesis, University of Warsaw. [In Polish].

8. Dobrowolska A., 1981: Serum transferrin polymorphism in common vole Microtus arvalis (Pall., 1779). Bull. Acad. Pol. Sci. Ser. Sci. biol., 29: 149-155.

9. Dobrowolska A., 1982a: Variability of transferrin in Microtus arvalis, (Pall.) inhabiting farmland. Pol. ecol. Stud., 7 [1981]: 257-269.

10. Dobrowolska A., 1982b: Serum gamma-globulin concentration in different stages of sexual activity in females of common vole Microtus arvalis, Pall. Comp. Biochem. Physiol., 71 A: 465-467.

11. Dobrowolska A. \& Gromadzka-Ostrowska J., 1983: Influence of photoperiod on morphological parameters, androgens concentration, haematological indices and serum protein fractions in common vole, Microtus arvalis (Pall.). Comp. Biochem. Physiol., 74A: 423-433.

12. Dżułyńska J., Krajewska K. \& Gill J., 1964: Serum glycoproteins in some species of non-domesticated mammals. Acta biochem. polon., 11: 121-128.

13. Fedyk A. \& Gębczyński M., 1978: Genetical changes in seasonal generation of the bank vole. Acta theriol., 25: 475-485.

14. Gaines M. S. \& Krebs Ch. J., 1971: Genetic changes in fluctuating vole populations. Evolution, 25: 702-723.

15. Gaines M. S., McClenaghan L. R. Jr. \& Rose R., 1978: Temporal pattern of allozymic variation in fluctuating populations of Microtus ochrogaster. Evolution, 32: 723-739.

16. Garten Ch. T., 1976: Relationshipe between agressive behaviour and genetic heterozygosity in the old field mouse Peromyscus polionotus. Evolution, 30: $59-72$.

17. Kostelecka-Myrcha A. \& Myrcha A., 1967: Variability of the leucocyte count in the blood of bank vole Clethrionomys glareolus (Schreber, 1870) under laboratory condition. Bull. Acad. Pol. Sci., Ser. Sci. biol., 15: 675-681.

18. Krebs Ch. J., 1979: Dispersal spacting behaviour and genetics in relation to population fluctuations in the vole Microtus townsendii. Fortschr. Zool., 25: $61-77$.

19. Mueller J. O., Smithies O. \& Irvin P. R., 1962: Transferrin variation in Columbidae. Genetics, 43: 1385-1392.

20. Mather K., 1970: The nature and significance of variation in wild populations. Symp. zool. Soc. Lond., 26: 27-39.

21. Nygren J., 1978: Interindividual influence on diurnal rhytms of activity in cycling and noncycling population of field vole, Microtus agrestis. Oecologia (Berl.), 35. 231-240.

22. Petrusewicz K., 1979: [The ecological rule by S. S. Schwarz]. Ekologija, 2: 8-11. [In Russian].

23. Pucek Z., 1965: Seasonal and age changes in the weight of internal organs of shrews. Acta theriol., 10: 369-438.

24. Ranshendakin Yo. O. \& Barmakin U. N., 1979: [The genetic nature and ecological amplitude of animals with wide and narrow form of geographical range of the genus Microtus]. Ekologija, 6: 11-21. [In Russian].

25. Rasmussen D. J., 1970: Biochemical polymorphism and genetic structure in population of Peromyscus. Symp. zool. Soc. Lond., 26: 335-349.

26. Schwarz S. S., 1975: Morpho-physiological characteristic as indices of population processes. [In: "Small mammals, their productivity and population 
dynamics"., Eds Golley F. B., Petrusewicz K., Ryszkowski L.]. Cambridge Univ. Press. 129-152. Cambridge.

27. Schwarz S. S., Pokrowski A. U., Istchenko V. G., Olenov V. G., Ovtchinnikowa N. A. \& Piastolowa O. A., 1964: Biological peculiarities of seasonal generation of rodent with special references to the problem of senescence in mammals. Acta theriol., 8: 11-43.

28. Tamarin R. H. \& Krebs C. J., 1969: Microtus population biology. II. Genetic changes at the transferrin locus in fluctuating populations of two vole species. Evolution, 23: 183-211.

29. Tomaszewska-Guszkiewicz K., Składanowska E. \& Zurkowski M., 1971: Badania nad polimorfizmem amylazy surowicy krwi bydła nizinnego czarno-białego w Polsce. Biul. Inst. Genetyki i Hodowli Zwierząt PAN, 24: 5-10.

Accepted, February 25, 1983.

Anna DOBROWOLSKA

\section{ZMIENNOSC TRANSFERYN I POZIOMU GAMMA-GLOBULIN SUROWICY KRWI NORNIKA ZWYCZAJNEGO}

\section{Streszczenie}

W niniejszej pracy przedstawiono i porównano zmienność fizjologiczną i genetyczną populacji nornika o różnej dynamice liczebności (populacje z północnych i południowych rejonów Polski).

Zmienność poziomu gamma-globulin była większa w grupach osobników juvenilnych niż średniowiekowych (Tabela 1,2), szczególnie w grupach osobników aktywnych płciowo odlawianych wczesnym latem. W tej grupie fizjologicznej obserwowano najbardziej regularne sezonowe różnice zmienności indywidualnej badanego parametru (Ryc. 1). Współczynnik zmienności dodatnio korelował z liczebnością w przypadku osobników nieaktywnych płciowo, a ujemnie w przypadku aktywnych (Tabela 6). Korelacja zmienności poziomu gamma-globulin z liczebnością była istotna dla mało liczebnych populacji z Północnej Polski. Na Południu jednak w roku zwiększonej liczebności obserwowano znacznie większą zmienność poziomu gamma-globulin w okresie (wczesne lato) poprzedzającym okres wysokich poziomów frakcji (późne lato) i dużej liczebności (jesień) (Tabela 3, Ryc. 2).

Zmienność transferyn była różna $\mathrm{w}$ kolejnych latach i równoległa dla populacji północnych i południowych. Korelowała ona istotnie $\mathrm{z}$ liczebnością $\mathrm{w}$ przypadku populacji o większych liczebnościach (populacje południowe) (Tabela 6). Popopulacje te charakteryzowała większa przeżywalność zimowo-wiosenna heterozygot.

Fizjograficzna i klimatyczna charakterystyka badanych terenów wskazuje iż dominującym czynnikiem warunkującym obserwowane 'różnice w zmienności może być nawodnienie terenu. 